\title{
The General State Inspectorate - independent or under the executive - how does it compare with the Court of Accounts in Sub-Saharan Africa?
}

\author{
Andy Wynne - andywynne@lineone.net
}

The Inspection générale d'Etat is an African innovation, essentially presidential, which overturns generally accepted paradigms, especially of experts from countries under parliamentary, or at least non-presidential rule, which is significantly different from arrangements which exist elsewhere. (Gueye 2007: 199)

Quis custodiet ipsos custodes? - (Who audits the auditors?)

Juvenal, satirical Roman poet

\section{Abstract}

The INTOSAI Mexico Declaration provides a summary of good practice for the independence of government auditors. However, as in many parts of the world, this ideal is not achieved in many Sub-Saharan African countries. This includes both the English speaking and the French speaking countries. The picture is complex, especially in Francophone countries where there is usually more than one type of entity that provides some sort of audit function for central government. The roles and relative strengths of these different types of audit institution (usually Court of Accounts and General State Inspectorate) need to be clearly understood. This paper provides an introduction to their roles and considers their relative levels of independence against the INTOSAI guidance on independence from the Mexico Declaration. It concludes that, despite recent improvements, neither type of organisation achieves the levels of independence envisaged by INTOSAI nor are they adequately resourced. As a result co-operation between all public audit functions is more important than consideration of their relative levels of independence.

\section{Key words:}

General State Inspectorate, Court of Accounts, independence, government audit, Sub-Saharan Africa

\section{Introduction}

In almost all French speaking Sub-Saharan African countries there is a General State Inspectorate $^{31}$ (usually called an Inspection générale d'Etat, but other titles are used). This type of institution evolved in post-colonial Africa and so has no parallels in France, Canada or other industrial French speaking countries. Some public financial management advisors consider the General State Inspectorate to be an internal audit institution and most PEFA reports make this assumption. However, in around a third of Francophone African countries the General State Inspectorate is the Supreme Audit Institution and the member of INTOSAI for their country.

\footnotetext{
${ }^{31}$ In this paper this term is used for this type of organisation whatever the specific terms used in individual countries.
} 
It has been argued that General State Inspectorates should not be considered as external auditors or supreme audit institutions as they are part of the executive branch of government. In contrast the Courts of Accounts ${ }^{32}$ (Cours des comptes) are claimed to be outside and functionally independent of the executive.

General State Inspectorates are usually appointed by the president (or sometimes by the prime minister) and their annual reports are sent to these officials rather than to parliament. However, this may also be the case for Court of Accounts and, indeed for Auditors General in Anglophone countries. Independence is not easy to achieve or maintain for any Supreme Audit Institution. The current president of the Court of Accounts in France was, for example, appointed by Sarkozy, the French president, in early 2010. In addition, the judiciary and indeed parliaments in Sub-Saharan Africa do not have the independence achieved in many OECD countries, for example, the Africa Peer Review Mechanism (2008: 120) report on Burkina Faso concluded that:

the Executive is dominant and is hardly limited by the legislature and the judiciary, both of which are weak as regards checks and balances.

This paper uses INTOSAI guidance to assess the relative levels of independence of the General State Inspectorate and the Court of Accounts in Francophone Sub-Saharan African countries.

In 2007 INTOSAI, the international body of Supreme Audit Institutions (including Courts of Accounts, General State Inspectorates and Auditors General as its members), then meeting in Mexico, issued a declaration on independence (INTOSAI, 2007). This Mexico Declaration includes the following eight principles on independence:

- The existence of an appropriate and effective constitutional/statutory/legal framework and of de facto application provisions of this framework

- The independence of SAI heads and members (of collegial institutions), including security of tenure and legal immunity in the normal discharge of their duties

- A sufficiently broad mandate and full discretion, in the discharge of SAI functions

- Unrestricted access to information

- The right and obligation to report on their work

- The freedom to decide the content and timing of audit reports and to publish and disseminate them

- The existence of effective follow-up mechanisms on SAI recommendations

\footnotetext{
${ }^{32}$ Similarly this term is used for this type of organisation whether an independent court (Cour des comptes) or part of the supreme court (Chambre des comptes).
} 
- Financial and managerial/administrative autonomy and the availability of appropriate human, material, and monetary resources.

\section{Multiple Audit Institutions in Many Countries}

INTOSAI requires each country to nominate a Supreme Audit Institution, however, in many countries there are several entities which contribute to the function of a Supreme Audit Institution. The public sector in most countries consists of a complex amalgam of different types of entities. These include central government ministries, departments and agencies, sub-national governments (states, provinces, local governments etc) and state owned enterprises (or parastatal organizations as they are usually termed in Africa). In many countries, the Supreme Audit Institution is only responsible for central government. So, for example, in the UK and US the Supreme Audit Institution is not responsible for the audit of local (or state) governments (as is also the case in Nigeria and Ethiopia). In France and other countries regional Courts of Accounts are responsible for the audit of local governments. In addition, in some countries, state owned enterprises are not audited by the Supreme Audit Institution, they may be audited by private audit firms (for example, in UK and Nigeria) or a separate institution, for example, the Audit Service Commission in Ethiopia and Eritrea (and previously in Tanzania). As a result, there is a spectrum of different approaches. In Ghana there is a powerful Auditor General who is responsible for the audit of almost the totality of the public sector, in contrast in Nigeria there are 74 Auditors General and none of them are allowed to audit the accounts of state owned enterprises (Wynne 2010).

\section{Models of Supreme Audit Institution in Francophone Sub-Saharan Africa}

Francophone Sub-Saharan African countries have two types of institution which undertake external audit type functions, either of which may be designated as the Supreme Audit Institution for an individual country:

- the Court of Accounts is a division of the Supreme Court or separate court within the judicial system. The individual members of the court (judges or magistrates) are led by a president who is generally appointed by the president of the relevant country. The court, with the support of its staff, judges the legality and regularity of the transactions and accounts of individual public accountants and reports to Parliament on the overall State Account. There is limited follow up of the Court's reports by Parliament. The professional staff traditionally have a legal rather than accounting or audit backgrounds, but this is expanding in several countries

- the General State Inspectorate reports either to the president or the country's prime minister (rather than to parliament), but it is largely independent of the state bureaucracy and has access to all state institutions, public servants and their documents. It usually largely sets its own annual programme. The professional staff of the General State Inspectorate are usually educated in public financial management at specialist higher education institutions. If irregularities are found they are reported to the relevant ministry or other agency for appropriate action to be taken (Wynne, 2010). 
The Court of Accounts, as part of the judiciary, may be considered to be independent of the executive, but their members may be appointed by the president or the council of ministers and their reports may not be submitted direct to parliament. The Court of Accounts produces two annual reports. The first is sent to all members of parliament and reviews the execution of the budget. The second annual public report is sent to the president rather than to parliament and may be made public (Bouvier, Esclassan \& Lassale, 2004).

The main thrust of audit reforms in Francophone Sub-Saharan African countries in recent years has been the move from the Court of Accounts being a chamber of the supreme court (Chambre des Comptes) to being a court in its own right (Cour des Comptes). However, unless the appointment of the court's president and magistrates is changed, the courts are provided with greater resources and the relationship with parliament is strengthened it is not clear that such reforms will greatly improve the independence of the Court of Accounts (Wynne, 2010).

As the General State Inspectorate is accountable to the president (or the prime minister) they may also have a high degree of independence from the entities (ministries, departments and agencies) which they audit. A distinction could perhaps be made between independence from the executive and independence from the entities which are subject to audit. If the General State Inspectorate has the support of a strong president they may in fact have considerably more independence from the ministries and other bodies which they audit than a Court of Accounts whose budget is usually submitted through the Ministry of Finance before being agreed by parliament (Wynne, 2010). In addition, there has been a trend in recent years for more General State Inspectorates to make their annual reports public.

The following General State Inspectorates are all members of INTOSAI and so are the Supreme Audit Institutions for their countries (each of these countries also has a Court of Accounts or equivalent):

- $\quad$ Burundi - Inspection Générale de l'Etat

- Cameroon - Contrôle Supérieur de l'Etat

- Centrafrique - Inspection Générale d'État

- Guinée Conakry - Inspection Générale d'État

- Mali - Contrôle Générale des Services Publics

- Togo - Inspection Générale d'État.

Until 2007 the General State Inspectorate of Burkina Faso was also the member of INTOSAI for that country. 
Table 1: Names of the General State Inspectorate and Court of Accounts in larger Francophone African Countries

\begin{tabular}{|c|c|c|}
\hline Country & General State Inspectorate & Court of Accounts \\
\hline $\begin{array}{l}\text { Democratic } \\
\text { Republic of the } \\
\text { Congo }\end{array}$ & Inspection générale de finance & $\begin{array}{l}\text { Cour des Comptes et de Discipline } \\
\text { Budgétaire } \\
\text { www.ministeredubudget.cd/audit_co } \\
\text { ur_comptes.html }\end{array}$ \\
\hline Ivory Coast & $\begin{array}{c}\text { Inspection générale d’Etat } \\
\text { www.cotedivoirepr.ci/ } \\
\text { index.php?action=show_page\&id_ } \\
\text { page }=27\end{array}$ & $\begin{array}{c}\text { Cour des Comptes } \\
\text { (not yet fully established) } \\
\text { www.courdescomptesci.com }\end{array}$ \\
\hline Madagascar & Inspection générale d’Etat & $\begin{array}{l}\text { Cour des Comptes de la Cour } \\
\text { Suprême }\end{array}$ \\
\hline Cameroon & Contrôle Supérieur de l'Etat & $\begin{array}{c}\text { Chambre des comptes } \\
\text { www.chambredescomptes.net }\end{array}$ \\
\hline Burkina Faso & $\begin{array}{c}\text { Autorité Supérieure de Contrôle } \\
\text { d’Etat } \\
\text { www.gouvernement.gov.bf/spip.ph } \\
\text { p?article6 }\end{array}$ & $\begin{array}{c}\text { la Cours des Comptes } \\
\text { www.cour-comptes.gov.bf }\end{array}$ \\
\hline Mali & $\begin{array}{c}\text { Contrôleur Général des Services } \\
\text { Publics }\end{array}$ & $\begin{array}{c}\text { Section des Comptes de la Cour } \\
\text { Suprême } \\
\end{array}$ \\
\hline Niger & Inspection générale d’Etat & $\begin{array}{c}\text { Cour des Comptes } \\
\text { (not yet fully established) } \\
\text { www.niger- } \\
\text { gouv.ne/coursupreme.htm }\end{array}$ \\
\hline Senegal & $\begin{array}{l}\text { Inspection générale d'Etat } \\
\text { www.ige.sn/ }\end{array}$ & $\begin{array}{c}\text { Cour des Comptes } \\
\text { www.courdescomptes.sn }\end{array}$ \\
\hline
\end{tabular}

For the above eight largest Francophone countries the Court of Accounts is the Supreme Audit Institution and member of INTOSAI for the country except for Cameroon and Mali where it is the Inspection générale d’Etat.

Wide Scope of Francophone Supreme Audit Institutions

Both the General State Inspectorate and the Court of Accounts have a wider scope than would be expected for Auditors General in Anglophone countries. They have the power to follow public money, something that was only recommended in the UK by the Sharman review in 2001 (Sharman). This report defined public money as:

All money that comes into the possession of, or is distributed by, a public body, and money raised by a private body where it is doing so under statutory authority (Sharman 2001: 15)

The Sharman report also recommended that public money should be subject to audit by public auditors. This principle is generally followed in Francophone countries and the General State Inspectorate and the Court of Accounts have a wide remit to audit the following: 
- all public services, offices and organizations

- local authorities

- parastatal bodies, public companies, enterprises and establishments

- public projects and development agencies

- any bodies benefiting from public financial support (state aid).

The final bullet point may be extended to include all bodies making public appeals for funds and so may include insurance companies, pension funds and trade unions. In Cameroon this may be extended still further and the General State Inspectorate may audit any private bodies that are strategic for the nation or related to national defence. In Senegal the scope of the Court of Accounts includes all those organizations in the above bullet points, all organizations controlled directly or indirectly by these entities and national appeals for funds from the public and the organizations benefiting from such appeals (World Bank 2009).

\section{Specific Role of the Court of Accounts}

In contrast to this wide scope, the Court of Accounts, has a very limited role. The core and original role of the Court of Accounts is to confirm or otherwise the legality of the accounts of the public accountants. If their accounts are found to be legal and regular, the public accountant is given quietus, or full discharge, and so is freed of any further personal or financial responsibility for the sums of money that they have paid (Bouvier, Esclassan \& Lassale 2004). If any errors or irregularities are found then the public accountant may be required to repay the money concerned and, in addition, they may be required to pay a fine.

The other core role of the Court of Accounts is to provide a report which is sent with the budget out-turn report (financial statements - loi de règlement) of the government to the National Assembly. This report may include some broad comments on the level of payments and receipts by the government compared to the budget for the relevant financial year and also a commentary of the general economic and financial environment of the country (Court of Accounts of Ivory Coast 2006a). This report also includes a formal opinion or certificate of conformity between the level of payment orders paid by the public accountants and the value of the payments orders raised by the officials with responsibility for raising orders (ordonnateurs) (Lienert 2003).

Thus, for example, in the Democratic Republic of the Congo, the first paragraph of article 52 of the Organic Law on State Finances requires that, "the draft budget out-turn report is accompanied by a report of the Court of Accounts and a general declaration of conformity between the administrative account [of the ordonnateurs] and the management account [of the public accountants] (Court of Accounts, Democratic Republic of the Congo, 2009).

In addition to this report to the National Assembly, the Court of Accounts provides a General Public Report on the activities of the Court. This is usually addressed to the President and may be made public. This provides general background details of the activities of the Court of Accounts for the year concerned, significant developments, major findings and may include details of training received. It will also usually include a summary of the main activities of the Court and any significant developments. This may also include a summary of the reports to the 
National Assembly including the formal opinion on conformity between the administrative account and the management account (Court of Accounts, Burkina Faso, 2009).

The above core role of the Court of Accounts is largely limited to an audit of the activities of the public accountants. The audit of other public officials with financial responsibilities may be added to the role of the Court of Accounts through a separate court or chamber, the Court of Budgetary Discipline. This may be part of the Court of Accounts, as in the case of France (Institut Montaigne 2005), and, for example, the Democratic Republic of the Congo where the Court of Accounts is named the Court of Accounts and Budgetary Discipline (la Cour des Comptes et de Discipline Budgétaire) (Court of Accounts, Democratic Republic of the Congo, 2009). In other countries, the Court of Budgetary Discipline may be a separate institution from the Court of Accounts. For example, in Cameroon, the Commission of Budgetary and Financial Discipline has five members and is headed by the General State Inspector.

These quite specific roles of the Court of Accounts mean that the role of the General State Inspectorate may be complementary to the Court. In France, the role of the Court of Accounts has expanded. In Francophone Africa the General State Inspectorate has generally been used to fulfil these additional roles.

\section{Different ways of classifying public audit}

In Anglophone countries a distinction is usually made between the internal auditor and the external auditor (Auditor General). However, under the French tradition, the control of budgetary execution is divided in to administrative, jurisdictional and parliamentary control. Administrative control is exercised by a number of entities. These generally include the Financial Controllers, General Financial Inspectors and the General State Inspectorate. In the French approach the General State Inspectorate is seen as the supreme body for administrative control (Abdourhamane, Crouzel and Claassens 2004, Bouvier, Esclassan and Lassale 2004). Many Anglophone experts consider that each of these three bodies to be internal audit functions. However, the last two at least can equally considered to be external audit functions as they report externally to the bodies they are reviewing. The General Financial Inspectors review financial operations and management across central government ministries, departments and agencies on behalf of the Minister of Finance. Similarly the General State Inspectorate review all ministries, departments and agencies on behalf of the President. Unlike internal auditors, these two bodies do not provide advice to the management of the organizations that they review, but are monitoring, reviewing or auditing the organizations on behalf of a third party.

Jurisdictional control is exercised by the Court of Accounts and related bodies, for example, regional courts of audit and Courts of Budgetary Discipline. These bodies are courts, rather than audit institutions, and their senior officials are magistrates or judges. Public financial management officials are tried by the Court of Accounts. If they are found guilty of responsibility for an irregularity may be required to pay a fine. The Court of Accounts assists the President of the Republic, the Government and the National Assembly in the control of the execution of the budget (Constitution of Senegal 2001). 
Parliamentary control is exercised by the National Assembly. Before the beginning of the financial year the National Assembly passes the annual budget allowing the government to collect revenue and make payments (finance law or loi de finance). At the end of the year the National Assembly passes the budget out-turn report (loi de règlement) this reconciles actual receipts and payments to the annual budget. It is the act by which parliament accepts the receipts and payments made by the government on its behalf.

Thus under the French system there are three bodies which are supreme in terms of monitoring and controlling their aspect of the budget. These are the General State Inspectorate (administrative control), the Court of Accounts (judicial control) and the National Assembly (parliamentary control).

\section{Origins of the General State Inspectorate}

Under the French approach, there are a series of inspectors for each public service, for example, inspectors of education, inspectors of health etc. In 1906 the Governor General of French West Africa created the Inspection Service of Administrative Affairs. This body reported directly to the Governor and provided findings and propositions, which were less prescriptive than recommendations (Gueye 2008).

This service was reorganized in 1936 and again in 1937. At this stage the service was independent and essentially mobile. Inspectors were not allowed to take on other management or executive responsibilities. The scope of their work was now all the administrative services except for the treasury and the technical services of the colonies head quarters. The inspectors had the obligation to inspect each territorial region every year and to provide an annual report of their activities, observations and follow up (Gueye 2008).

In 1943 the name of this service was changed to the General Inspection of Administrative Affairs. The General Inspector was nominated by decree of the Governor and chosen from amongst the governors of the colonies or the chief administrators. The service was based in Dakar and covered all of French West Africa (Gueye 2008).

With independence, the General Inspection of Administrative Affairs reported to the President of the Council and then to the President of the Republic. The General State Inspectorate was formed in Senegal in 1964. Similarly in Togo, the General State Inspectorate was established in 1972 from the Permanent Mobile Inspection of Administrative and Financial Services. In 1982 a General State Inspectorate (Contrôle Général des Services Publics) was formed in Tunisia from the previous Inspection Générale des Services Administratifs (Prime Minister, Tunisia 2010).

The independent Francophone countries generally had strong presidents and weak or nonexistent parliaments. In these circumstances it would appear to make more sense to have a public audit institution which reports to the president rather than to parliament. As a result, in several independent Francophone African countries General State Inspectorates were established. In contrast, the Court of Accounts in these countries did not exist or in name only. So, for example, in Burkina Faso, although the Court of Accounts was mentioned in the 1960 constitution it was not, in reality established until 2002 (PEFA 2010). Similarly in Mali, the 
Court of Accounts has been referred to in the constitution since independence in 1960.

However, it only produced four reports in the twenty years leading to 2008. Again in Cameroun, a Court of Accounts was only established in its current form in 2003 and the General State Inspectorate was and continues to be the main public audit body. As a result, for at least the four decades after independence, it was the General State Inspectorate that was the main public audit body and so was nominated as the member of INTOSAI in these three countries (as in several other Franco-phone African countries).

More recently General State Inspectorates were also established in countries which did not have them before, for example, in Djibouti in 2004 and in Mauritania in 2005. In 2001 the Commission on Reform of Structures and Missions of the State in Algeria recommended the formation of a General State Inspectorate reporting to the President to control the functioning of all public services and administration. This was to have been in addition to the Court of Accounts which reviews the financial operations linked to budget execution.

In addition, General State Inspectorates were created in 2009 in Burundi and the Democratic Republic of the Congo by moving the General Inspectorate of Finance into the Office of the President.

In Djibouti, despite the already existing Court of Accounts, a General State Inspectorate was established in law in 2001. The idea was that the ex post juridical control (after the event legal control) of the Court of Accounts would be complemented by a body which could act during the implementation of the budget (General State Inspectorate, Djibouti, 2007). The general state inspectorate has developed its own approach to audit which takes in to account all management sub-systems, "this includes:

- evaluating whether the character of new or existing programmes are effective, appropriate or pertinent considering their objectives and whether the expected results are achieved

- identifying constraints and performance factors and whether management has identified alternative solutions or the opportunity costs to achieve the programme's objectives effectively and efficiently

- identifying any overlaps or duplications or conflicts with other programmes and recommending ways of executing programmes in the best manner possible

- evaluating programmes for conformity with laws and regulations, but also the adequacy of systems of internal control and especially systems to monitor their success" (page 10/11).

This first annual public report from the general state inspectorate of Djibouti (General State Inspectorate, Djibouti, 2007: 24) also notes that:

"The general state inspectorate is a concept specific to Africa, with a universal, general and extended scope. It usually consists of elite staff recruited through competition from 
amongst the highest officials of the state (magistrates, national directors, secretaries general of ministries etc), at least in Sénégal, Burkina Faso, Côte d'Ivoire etc."

This evolution and the spread of the formation of General State Inspectorates shows that the value and the usefulness of such organizations has been clearly demonstrated and recognized across Francophone Africa.

Responsibilities for value for money and anti-corruption

In recent years at least some General State Inspectorates have taken on responsibility for value for money or performance audit. In Senegal, for example, with the legal amendments in 2005 and 2007 the work of the General State Inspectorate was reoriented towards value for money or performance audit (Keita 2007).

The clearest example of a General State Inspectorate taking on responsibility for anti-corruption work is in Burkino Faso where the Supreme Control Authority of the State (Autorité Supérieure de Contrôle d'Etat) was formed in 2007 from the following bodies (General State Inspectorate, Burkina Faso 2009):

- General State Inspectorate (Inspection Générale d’Etat)

- Higher Authority for Co-ordination of the Fight Against Corruption (Haute Autorité de Coordination de la Lutte contre la Corruption), and

- Part of the National Co-ordination of the Fight Against Fraud (Coordination Nationale de Lutte contre la Fraude).

Following this introduction, the relative independence of the General State Inspectorates and the Courts of Accounts in Francophone Africa are assessed against each of the eight principles from the INTOSAI Mexico Declaration. The position in the following eight largest Sub-Saharan African Franco-phone countries is investigated in detail (however, other smaller countries and north African countries are also referred to):

- Democratic Republic of Congo

- Ivory Coast

- Madagascar

- Cameroon

- Burkina Faso

- Niger

- Mali

- Senegal

The paper finishes with some conclusions and final thoughts. 


\section{Principle 1: The existence of an appropriate and effective constitutional/statutory/legal framework and of de facto application provisions of this framework}

\section{Guidelines}

Legislation that spells out, in detail, the extent of SAI independence is required (INTOSAI 2007b).

The Court of Accounts is referred to in the Constitution of all eight of the larger Francophone Sub-Saharan African countries. However, the provisions are not necessarily appropriate in terms of the Mexico Declaration.

The Monetary and Economic Union of West Africa (UMEOA) Code of Transparency (2000) required its members states to establish an autonomous Court of Accounts by the end of 2002 (paragraph E2-2). However, in a review in early 2010 this had only been achieved in half the member states.

The General State Inspectorate was the INTOSAI member for Burkina Faso until 2007. This was despite the constitution (Article 127) from 2000 saying that, "The Court of Accounts is the superior legal body for the control of public finances ${ }^{33}$."

In most cases the President (some times through the Council of Ministers) appoints the members of the Court of Accounts, it is the President that guarantees the independence of the judiciary according to the Constitution and the reports of the Court of Accounts are sent to the President (and may also be sent to National Assembly). It is only the 2006 Constitution of the Democratic Republic of the Congo which provides for the involvement of the National Assembly in the appointment or removal of the President of the Court of Accounts. In this case the National Assembly advises the President (Democratic Republic of the Congo 2006).

The Constitutions do not necessarily emphasize the general relationship of the Court of Accounts with the National Assembly, for example, the 2001 Constitution of Senegal states that the "Court of Accounts assists the President of the Republic, the Government and the National Assembly in the control of the execution of the budget”. Similarly the 2006 Constitution of Democratic Republic of the Congo requires the annual report of the Court of Accounts to be sent to the President of the Republic, Parliament and the Government. It is only this Constitution (of the eight largest countries) which requires the annual report of the Court of Accounts to be published. Similarly, the constitution of the Democratic Republic of the Congo provides for a clear relationship with parliament. The second paragraph of article 178 of this constitution states that the: "Court supports the National Assembly" (Democratic Republic of the Congo 2006). Similarly the Constitution of Burkina Faso (2002) states that the National Assembly is assisted in controlling the accounts of the nation by the Court of Accounts which it may require to undertake any enquiry or study on public financial management (article 105).

\footnotetext{
33 "La Cour des comptes est la juridiction supérieure de contrôle des finances publiques.”
} 
These Constitutional provisions do not necessarily provide the Courts of Audit with the independence they require. The State President is often the guarantor of independence of the judiciary (Côte d'Ivoire, Cameroon, Burkina Faso and Mali). However, the president may use this power to restrict the work of the Court of Accounts, for example, the President of Senegal threatened to close the Court of Accounts over its plans to review the management of an agency managed by his son and an NGO employing his wife. Only the intervention of the IMF stopped the budget of the Court of Accounts being cut by two thirds (World Bank 2009). In Algeria the current President has stopped the publication of the annual general activity report of the Court of Accounts since he came to power in 1999. In 1969 the Court of Accounts of Cameroon was suppressed by Presidential decree and it was not re-established until 1996 (Bizeme 2010)

The provisions of the Constitution are generally supported by more detailed laws. In some cases, for example the Democratic Republic of the Congo and Burkina Faso, this is an organic law which provides more protection against amendment than a normal law. However, the laws may not be up to date, apply best practice or be implemented as required. The law creating the Chamber of Audit in Democratic Republic of the Congo has not been amended since 1987 and so the Court of Accounts does not have legal backing. In Côte d'Ivoire, the Constitution refers to a Court of Accounts, but the law to support such a Court independent from the Supreme Court has yet to be agreed by the National Assembly (Court of Accounts, Côte d'Ivoire 2010).

In 2009 the Monetary and Economic Union for West Africa (UMEOA 2009) revised its requirements for the regulation of public financial management, including those governing the Court of Accounts. These regulations are not achieved by many of its members and in early 2010 UMEOA considered that in only three of its eight member countries did the Court of Accounts have functional financial autonomy (Senegal, Burkina Faso and Guinea Bissau).

Although Chambers (or Courts) of accounts were established constitutionally and legally from independence (1960) in severally countries these bodies did not come into effective existence until much later. For example, in Mali the Court of Accounts (Section of the Supreme Court) only produced four reports in the twenty years leading to 2008. Similarly in Burkina Faso, although the constitution made provision for a chamber of accounts it was not established in fact until 1984 when three judges were appointed. However, regular annual reports for the National Assembly and public reports were only produced from 2003-04 after the Court of Accounts had been established.

The proposed organic law of the Côte d'Ivoire will still allow the accounts of public accountants to be subject to the procedures of the Court of Accounts only at least every five years (World Bank 2009b).

The General State Inspectorates are not referred to in the Constitution of any of the eight larger countries, but their main attributes are detailed in laws which have all been amended within the last 15 years. These laws have usually been subject to regular reform so, for example, the General State Inspectorate in Senegal was created in 1964 and the relevant law was then amended in 1974, 1987, 2005 and 2007 (Keïta 2007). 
In all Francophone countries in Sub-Saharan Africa there is largely appropriate Constitutional and/or legal provision for both the Court of Accounts and the General State Inspectorate.

Neither with the case of the Court of Accounts nor the General State Inspectorate do the legal provisions provide for any significant relationship with the National Assembly in ensuring their independence. In addition, the state President in each country (sometimes through the council of ministers) usually appoints the heads of both types of institution. This aspect is considered further in the next section.

\section{Principle 2: The independence of SAI heads and members (of collegial institutions), including security of tenure and legal immunity in the normal discharge of their duties}

\section{Guidelines:}

The applicable legislation specifies the conditions for appointments, re-appointments, employment, removal and retirement, of the head of SAI and members of collegial institutions, who are:

- appointed, re-appointed, or removed by a process that ensures their independence from the Executive

- given appointments with sufficiently long and fixed terms, to allow them to carry out their mandates without fear of retaliation; and

- immune to any prosecution for any, act, past or present, that results from the normal discharge of their duties (INTOSAI 2007b).

In each of the eight larger countries in Francophone Sub-Saharan Africa the heads of both the Court of Accounts and the General State Inspectorate are appointed by the State President (usually through the Council of Ministers) as indicated by the following table:

Table 2: Mode of Appointment of the General State Inspectorate and Court of Accounts

\begin{tabular}{|c|c|c|}
\hline Country & General State Inspectorate & Court of Accounts \\
\hline $\begin{array}{l}\text { Democratic Republic of the } \\
\text { Congo }\end{array}$ & $\begin{array}{l}\text { Appointment by President on } \\
\text { the advice of the Minister of } \\
\text { Finance and Public } \\
\text { Administration (competitive } \\
\text { examination for staff) }\end{array}$ & $\begin{array}{l}\text { Members appointed by the } \\
\text { State President advised by the } \\
\text { National Assembly }\end{array}$ \\
\hline Ivory Coast & $\begin{array}{l}\text { General State Inspectors } \\
\text { appointed by the President }\end{array}$ & $\begin{array}{l}\text { President appointed from } \\
\text { amongst the magistrates }\end{array}$ \\
\hline Madagascar & $\begin{array}{l}\text { General State Inspectors } \\
\text { appointed by the President } \\
\text { through the Council of } \\
\text { Ministers }\end{array}$ & $\begin{array}{l}\text { President and members } \\
\text { appointed by the State } \\
\text { President advised by the } \\
\text { Higher Judicial Council }\end{array}$ \\
\hline Cameroon & $\begin{array}{l}\text { The head is appointed by the } \\
\text { President }\end{array}$ & $\begin{array}{l}\text { Members appointed by } \\
\text { Presidential decree }\end{array}$ \\
\hline
\end{tabular}




\begin{tabular}{|c|c|c|}
\hline Country & General State Inspectorate & Court of Accounts \\
\hline Burkina Faso & $\begin{array}{l}\text { The head and staff are } \\
\text { appointed by the Council of } \\
\text { Ministers (recent staff by } \\
\text { public competition with } 15 \\
\text { years of service) }\end{array}$ & $\begin{array}{l}\text { President and members } \\
\text { appointed by the Council of } \\
\text { Ministers advised by the } \\
\text { Higher Judicial Council } \\
\text { (which the state president } \\
\text { chairs) for a five year } \\
\text { renewable term }\end{array}$ \\
\hline Niger & $\begin{array}{c}\text { General State Inspectors } \\
\text { appointed by the Council of } \\
\text { Ministers } \\
\text { (new group of } 20 \text { appointed in } \\
\text { May 2010) }\end{array}$ & $\begin{array}{l}\text { First President appointed for a } \\
\text { four year term by the State } \\
\text { President on the advice of the } \\
\text { Minister of Justice with the } \\
\text { consent of the Higher Judicial } \\
\text { Council. Members of the } \\
\text { Court appointed by the State } \\
\text { President on the advice of the } \\
\text { Minister of Justice }\end{array}$ \\
\hline Mali & $\begin{array}{l}\text { General State Inspectors } \\
\text { appointed by the Council of } \\
\text { Ministers }\end{array}$ & $\begin{array}{l}\text { President and vice president } \\
\text { appointed by the State } \\
\text { President advised by the } \\
\text { Higher Judicial Council } \\
\text { Other members by Council of } \\
\text { Ministers }\end{array}$ \\
\hline Senegal & $\begin{array}{c}\text { Presidential decree for } \\
\text { appointment of the Auditor } \\
\text { General, } \\
\text { General State Inspectors are } \\
\text { appointed by competition for } \\
\text { senior officials of grade A } \\
\text { special or A1 with a least } 10 \\
\text { years of service } \\
\end{array}$ & $\begin{array}{l}\text { Members appointed by the } \\
\text { State President advised by the } \\
\text { Higher Judicial Council }\end{array}$ \\
\hline
\end{tabular}

The Court of Accounts may be considered to have more independence in terms of appointment of its members as the President is usually advised on their appointment by the Higher Judicial Council or the Minister of Justice. However, in Mali, for example, the "nomination of the members of the Court is more political than being based on their professional competences" (Ezeilo 2008: 28). Similarly, in Burkina Faso, the PEFA report (2007) noted that the procedure for the nomination of members of the Court of Accounts was not sufficiently based on competitive appointment and too much on nomination by the executive. Again, in Burkina Faso the State President is advised by the Higher Judicial Council on the appointment of the President and members of the Court of Accounts. However, the Higher Judicial Council is itself dominated by the executive with the State President as its chair and the deputy chair being the Minister of Justice and the State President nominating a third member of the seven person council (African Peer Review Mechanism 2008). 
The 2008 Open Budget Survey found that head of the Court of Accounts could be removed by the executive without the final consent of the judiciary or the legislature in the following countries: Democratic Republic of the Congo, Burkina Faso, Algeria, Chad, Equatorial Guinea and Morocco. Of the Francophone countries surveyed in Africa, only the heads of the Court of Accounts in Niger, Senegal and São Tomé e Príncipe had such protection.

The comment of the peer reviewer of the Court of Accounts of the Democratic Republic of the Congo (Global Integrity 2006) was that, "the head of the agency in Congo is not protected. If he has not been removed, it is because he works for the president. If his agency audits national accounts and issues reports critical of the government, I would make the case that he would be removed without defensible justification." They went on to say, "Appointments were political. So I do not see how they would support the independence of the agency”.

With the General State Inspectorate, in some countries the head is a clearly a political appointment, for example, in Cameroon and Burundi the head of the General State Inspectorate is a deputy minister. In early 2010 the new government in Niger appointed a new set of 20 General State Inspectors. In other countries the head of the General State Inspectorate may have more independence from the politicians. In Senegal, for example, the law was amended in 2005 with the appointment of an Auditor General (vérificateur général) for a fixed non-renewable term of seven years (Keita 2007). In this case and in some other countries, there is a tradition of appointing the head of the General State Inspectorate from within the service. However, in Burkina Faso, for example, the current head of the General State Inspectorate was appointed from outside the service.

The staff of the Court of Accounts and the General State Inspectorate generally have complete freedom in undertaking their work and this is guaranteed by law. The General State Inspectors in Burkina Faso, for example, are free for their assignments and do not receive any instruction. In Senegal their independence in the interpretation of the facts and the conclusions made is legally guaranteed (decree 2007).

By the 2004 law, "Administrations of Inspection or of Control of the public finances of Madagascar”, the General State Inspectorate is independent in the exercise of its work of inspection or control. It is only subject to the Constitution and the law. They cannot be disciplined or subject to legal proceedings for their conclusions, recommendations or in exercising their functions.

The independence of the General State Inspectorate in Cameroon is described in the following terms on the website of the Presidency:

"In the field, members of the mobile audit teams enjoy total independence from the administration and the entities subject to audit and have all powers of investigation. During their investigations auditors should not suffer any restriction to their freedom without the prior agreement of the President of the Republic" 


\section{Principle 3: A sufficiently broad mandate and full discretion, in the discharge of SAI functions}

\section{Guidelines}

SAIs should be empowered to audit the

- use of public monies, resources, or assets, by a recipient or beneficiary regardless of its legal nature;

- collection of revenues owed to the government or public entities;

- legality and regularity of government or public entities accounts and entities;

- quality of financial management and reporting; and

- economy, efficiency, and effectiveness of government or public entities operations.

Except when specifically required to do so by legislation, SAIs do not audit government or public entities policy but restrict themselves to the audit of policy implementation.

While respecting the laws enacted by the Legislature that apply to them, SAIs are free from direction or interference from the Legislature or the Executive in the

- $\quad$ selection of audit issues;

- planning, programming, conduct, reporting, and follow-up of their audits;

- organization and management of their office; and

- enforcement of the decisions where the application of sanctions is part of their mandate.

SAIs should not be involved or be seen to be involved, in any manner, whatsoever, in the management of the organizations that they audit (INTOSAI 2007b).

As indicated in the introduction to this paper both the Courts of Accounts and the General State Inspectorates usually have a wide mandate to review the whole of the public sector and other organizations in receipt of public funds. This is better than a number of OECD countries.

But especially Courts of Accounts may be restricted by their lack of resources and so their work often concentrates on the audit of accounts of Public Accountants. In Senegal, for example, the PEFA review of Dakar Council (January 2009) found that the Court of Accounts had undertaken some audit fieldwork in October 2008, but that their previous visit to the council had been in 1999. Similarly in Burkina Faso, the PEFA review in 2007 noted that the central government accounts had not been audited from 1983 to 2000 and those of local government since 1963. The 
accounts for central government were subsequently brought up to date with those 1985 to 2000 being agreed in May 2000 and finally the accounts for 2008 being agreed by the National Assembly in early May 2010.

Courts may also not have the legal power to undertake performance audit. General State Inspectorates, are however, more likely to have this power (as indicated above). So, for example, the law governing the General State Inspectorate in Senegal states that one of its ten objectives is to propose, "all useful measures to simplify and improve the quality of the administration, reduce management costs and increase efficiency (Official Journal 2005).

The Courts of Accounts usually have a large measure of autonomy on the work they undertake beyond judging the accounts of the Public Accountants. However, they may be requested to undertake other assignments, for example, the Court of Accounts in Algeria may have cases referred to it by the President of the legislature (Transparency International 2002). Similarly in Mali, the Court of Accounts may have cases referred to it by the State President, the Prime Minister or the President of the National Assembly (Ezeilo 2008). In the Democratic Republic of the Congo (PEFA 2008) and Madagascar (personal communication), the government or the State President may request the Court of Accounts to undertake specific assignments. In fact in 2007 most of the work undertaken by the Court of Accounts of the Democratic Republic of the Congo was at the request of the government (PEFA 2008). The Court of Accounts of Congo and Equatorial Guinea determine less than $80 \%$ of their annual programme (Dehove 2010).

The General State Inspectorates usually have their annual programmes agreed by their State President. In addition, in Senegal and Cameroon, for example, the terms of reference for each mission are signed off by the Presidency. However, in practice this may leave a wide measure of independence for the General State Inspectorate to determine its own work programme.

In Senegal the Auditor General (head of the General State Inspectorate) has stated that "the General State Inspectorate is neutral and objective in its work. It constitutes an impregnable fortress that cannot be at the service of any politician” (Rewmi.com 2007). "The general assembly of the General State Inspectorate develops an annual programme of work which is then passed to the President for approval. Generally the programmes are approved... But the President can require the General State Inspectorate to undertake an occasional mission”.

Similarly in Togo, the annual work programme of the General State Inspectorate is agreed to by the State President who may request occasional missions to be undertaken. However, this institution indicated that it sets less than $80 \%$ of its annual programme (Dehove 2010).

In Burkina Faso, the State President may request the Court of Accounts to undertake particular missions of enquiry (article 26, decree 2005-258 Covering the Approach to the Control of Financial Operations of the Government and other Public Organizations). The same law (article 23) states that the General State Inspectorate may be requested by the President, the Prime Minister or the Speaker of the National Assembly to undertake any study or inquiry whatever may be its subject. 
The 2007 PEFA report for Burkina Faso states that General State Inspectorate has a large measure of independence in determining the work it undertakes:

"The annual work programme (around 90\% of reviews) is determined by the General State Inspectorate. Each year the prime minister sends a formal letter of instruction to the General State Inspectorate which does not include detailed plans. The General State Inspectorate then develops its annual work programme and sends it to the Prime Minister for information" 34 (page 114).

The head of the General State Inspectorate in Burkina Faso stated in a recent interview that, "the law says that the General State Inspectorate is totally independent in the execution of his mission". However, much of the work of this institution is now taken up with investigating cases of alleged fraud or corruption.

An example of this occasional work is in Benin, where, in August 2009, the President attacked the trade unions after a two day strike and protest march against the rise in the cost of living, corruption and poor management of public finances. The President then asked the General State Inspectorate to investigate state support to the trade unions over the previous five years.

Most of the Courts of Audit and the General State Inspectorates generally have a sufficiently broad mandate and large discretion, in the discharge of their functions. However, the Courts of Audit may be restricted in their legal mandates, and the level of resources they are provided with, to undertaking audits of the accounts of public accountants. They may not have the express legal power to undertake performance audit. At least some of the General State Inspectorates are also restricted by having their annual work plans and the terms of reference agree by the State President. However, they generally have a wider remit than the Courts of Audit and often have the express power to undertake performance audit and anti-corruption work.

\section{Principle 4: Unrestricted access to information}

\section{Guideline}

SAIs should have adequate powers to obtain timely, unfettered, direct, and free access to all the necessary documents and information, for the proper discharge of their statutory responsibilities.

Members of the Courts of Accounts and General State Inspectorates generally have full access to the information they need to complete their assignments. The only member of CREFIAF which said it did not have free access to information, the ability to review evidence and to visit the necessary offices was Guinea (a General State Inspectorate) (Dehove 2010).

$34 \quad$ La programmation annuelle (environ 90\% des contrôles) ne dépend que de l'IGE ; le premier ministre envoie chaque année une lettre de mission formelle à l'IGE sans instruction de contrôle précis, l'IGE élabore son programme de travail et le transmit pour information au Premier ministre. 
In Senegal the members of the Court of Accounts have wide access to information in the field of their investigations (PEFA 2007). Similarly, officials of the General State Inspectorate have their rights of access, enshrined in law and these are superior to many other African Supreme Audit Institutions. They have access to all documents even if classified confidential or secret, including secret national defense documents (Wynne 2010).

According to the State President of Senegal, Abdoulaye Wade:

"The General State Inspectorate should be protected from all sides to ensure its total freedom, because the role of the General State Inspectorate consists of making fully objective reports and improving the management and the very difficult weaknesses in public administration" "35 (Adigbli 2008).

The website of the General State Inspectorate of Côte d'Ivoire (2010) says that:

"When undertaking their inspections, the General State Inspectors have all the powers of investigation, information and interpretation. They have access to all sources of information and documentation, files, registers, correspondence, accounts etc and generally all documents that they judge necessary to fulfil their missions. No information may be refused even by private sector organizations relative to audited bodies. They are independent of the management that they inspect and their appreciation of the things they examine and the conclusions they draw."

Each Inspector of the General State Inspectorate of Cameroon has an identity card including their photograph and the personal signature of the President. This card details the access the Inspector has to any officials or documents required for them to undertake their work. If necessary, the card empowers the police to enable this access without delay.

The report of the Court of Accounts of the Democratic Republic of the Congo for 2006-07 states that:

Despite the importance attached by the Government to this task, the Court of Auditors noted the lack of willingness and cooperation from the heads of Departments and Services (page 3) ${ }^{36}$.

Thus in practice staff of the Court of Accounts and General State Inspectorate may not receive the co-operation they require to do their work effectively.

\footnotetext{
35 « l'IGE doit être protégée de tous les côtés, de façon à lui assurer une liberté totale, parce que, explique-t-il, le rôle des IGE consiste à faire des rapports en toute objectivité et de redresser le fonctionnement et les insuffisances de l'administration publique très difficile »

36 « En dépit de l'importance accordée par le Gouvernement a cette mission, la Cour des comptes a noté le peu d'empressement et de collaboration de la part des responsables des Ministères et Services. "
} 


\section{Principle 5: The right and obligation to report on their work}

\section{Guidelines}

SAIs should not be restricted from reporting the results of their audit work. They should be required by law to report at least once a year on the results of their audit work.

Most Supreme Audit Institutions in Francophone Africa produce an annual report which is made public. But few institutions are able to communicate with the public and none of the Court of Accounts or General State Inspectorates said they were feely able to do so in the recent CREFIAF survey (Dehove 2010). Four of these institutions said they did not produce an annual report (three Courts of Accounts and one General State Inspectorate) (Dehove 2010).

The Court of Accounts of Cameroon issued is first annual report (for 2006) in over thirty years in December 2007.

"The reports of the Court of Accounts in Mali are supposed to be public documents, but, in reality they are far from being accessible to the public” (Ezeilo 2008). In addition, the Court of Accounts has only produced two reports in the last ten years.

In Algeria the current President has stopped the publication of the annual report of the Cour des comptes since he came to power in 1999.

The General State Inspectorate of Senegal may publish its reports if they have been declassified by the President. It has developed "a new communications strategy with the right to inform the citizens... In this framework, the General State Inspectorate will present, each year, a report on the state of public governance” (Keïta 2007).

Courts of Audit have little contact with the National Assembly, even when their reports are considered by the National Assembly there may be little exchange of information. For example, the Finance Committee of the National Assembly of Burkina Faso considered the budget outturn report for 2006 in two meetings in March 2008 (lasting in total nearly six hours). The agenda for the meetings suggested that the Court of Accounts would be interviewed and questioned for 3.5 hours. However, the actual reports of these meetings indicate that although staff of the Court of Accounts were present, they had no clear role and their input was not reported (Commission des Finances et du budget 2008).

Both the Courts of Accounts and General State Inspectorate now generally provide annual reports on the results of their audit work, but these reports may not necessarily be made public. 


\section{Principle 6: The freedom to decide the content and timing of audit reports and to publish and disseminate them}

\section{Guidelines}

SAIs are free to decide the content of their audit reports.

SAIs are free to make observations and recommendations in their audit reports, taking into consideration, as appropriate, the views of the audited entity.

Legislation specifies minimum audit reporting requirements of SAIs and, where appropriate, specific matters that should be subject to a formal audit opinion or certificate.

SAIs are free to decide on the timing of their audit reports except where specific reporting requirements are prescribed by law.

SAIs may accommodate specific requests for investigations or audits by the Legislature, as a whole, one of its commissions, or the government.

SAIs are free to publish and disseminate their reports, once they have been formally tabled or delivered to the appropriate authority — as required by law.

There are two main reports of the Court of Accounts:

- Public Report - annual activity report and findings/recommendations from audits of institutions undertaken (Le Rapport Public).

- Reports accompanying the budget out-turn report (sent to the president to send on to the National Assembly with the draft budget out-turn law)

o presentation on the budget out-turn, observations and recommendations

o report of conformity between the accounts of the general financial administration and the accounts of the principal public accountants.

The Code of Transparency of UMEOA (2009) states that:

The Court of Accounts makes public all the reports it transmits to parliament, the government and the state president. Similarly it publishes all its specific decisions on its website, if it exists, and in at least two major national newspapers with a large circulation (5.7).

The general activity report of each Court of Accounts is usually made public, but this is not the case for Madagascar, Mali or Niger.

The annual reports for the General State Inspectorates are not usually made public, although this is improving. The General State Inspectorate of Burkina Faso publishes their annual reports on their website, as does the General State Inspectorate for Djibouti. The General State Inspectorate 
for Senegal also plans to move in this direction. It is committed to producing an annual report on the state of public governance for the citizens of Senegal. Generally the reports are sent to the State President and may then be made public (Wynne 2010).

A summary of the position on publication of annual reports is shown in the following table:

Table 4: Publication of Reports

\begin{tabular}{|l|c|c|}
\hline \multicolumn{1}{|c|}{ Country } & General State Inspectorate & Court of Accounts \\
\hline $\begin{array}{l}\text { Democratic Republic of the } \\
\text { Congo }\end{array}$ & - & $\begin{array}{c}\text { Official Journal } \\
\text { (2006-07 report on Internet }- \\
\text { only covers three months) }\end{array}$ \\
\hline Ivory Coast & Official Journal & - \\
\hline Madagascar & - & Internet \\
\hline Cameroon & - & Internet and Official Journal \\
\hline Burkina Faso & Internet & - \\
\hline Niger & - & - \\
\hline Mali & - & Internet \\
\hline Senegal & - & \\
\hline
\end{tabular}

The annual reports of the Court of Accounts of Cameroon are posted on its website. The report for 2008 is the latest available (in December 2010) and was published in October 2009. The reports for 2006 and 2007 are also available from the website.

A comment from the peer reviewer of the 2006 Global Integrity Report for the Democratic Republic of the Congo about the reports of the Court of Accounts was that, "The audit reports are accessible at a prohibitive price. They are generally published as special items in the official bulletins which cost between 2,500 and 5,300 Congolese francs or between US\$5 and US\$10. This amount represents a significant portion of the salary of middle class citizens (journalist, high school teacher, etc)". Thus the reports may be available to journalists, but they would not be available to the overwhelming majority of the population. The report available from the internet only covers the three months from December 2006 to February 2007.

Similarly, a researcher on the Courts of Accounts of Mali and Niger could not gain access to the reports of either institution (Ezeilo 2008).

The reports for the Court of Accounts of Congo, Djibouti and Guinea Bissau are not issued to parliament (Dehove 2010). The Court of Accounts of Madagascar did not produce an annual report (PEFA 2006), but one was produced and made public in 2009 (personal communication). 
In Burkina Faso the annual reports of the General State Inspectorate and the Court of Accounts can both only be published with the permission of the State President (PEFA 2010), but in practice both reports are made public immediately after they have been issued to the State President. In addition, the content of the reports is determined by the institution itself. However, this has only been the case in the last five years for the Court of Accounts and the last three years for the General State Inspectorate. The General State Inspectorate manages to produce an annual report which is publically available within three or four months of the end of the year. In contrast, the Court of Accounts only produces its report by the end of the following year and this refers to the financial year for the year before. So for example the 2009 public report (on the 2008 financial year) of the Court of Accounts was nearly ready for publication at the end of 2010.

In Côte d'Ivoire, in 1990, it was obligatory for the annual public report of the Court of Accounts to be sent to the National Assembly and to be published in the Official Journal (Tam: 339):

However, the issue, publication and distribution [of the annual report of the Court of Accounts in Senegal] is not obligatory. It depends on the State President who is the sole judge of this opportunity.

Since 2001, the annual reports of the Court of Accounts of Senegal have been made available on its website. The report for 2001 said that it was its second General Public Report.

In recent years there has been a general increase in the publication of the annual reports of both the Court of Accounts and the General State Inspectorate. The annual public reports of the Courts of Accounts are usually publically available (in five of the eight largest countries). In contrast, for the General State Inspectorates, their annual reports are currently (early 2011) only publically available in two of the largest Francophone countries. In late December 2010 the General State Inspector of Niger, Gabriel Martin appeared on state television to provide an interim report of the work of the General State Inspectorate (Martin 2010).

\section{Principle 7: The existence of effective follow-up mechanisms on SAI recommendations}

\section{Guidelines}

SAIs submit their reports to the Legislature, one of its commissions, or an auditee's governing board, as appropriate, for review and follow-up on specific recommendations for corrective action.

SAIs have their own internal follow-up system to ensure that the audited entities properly address their observations and recommendations as well as those made by the Legislature, one of its commissions, or the auditee's governing board, as appropriate.

SAIs submit their follow-up reports to the Legislature, one of its commissions, or the auditee's governing board, as appropriate, for consideration and action, even when SAIs have their own statutory power for follow-up and sanctions. 
The Code of Transparency of UMEOA (2009) states that the Court of Accounts should:

Follow-up the extent of implementation of its recommendations and the results of this exercise should be regularly brought to the attention of the public (5.7).

However, the parliamentary commissions of Francophone countries rarely follow-up on recommendations made by either the Court of Accounts or the General State Inspectorate. The Finance Commission for Burkina Faso did include such a review in its report on the 2006 budget (Commission des Finances et du budget, 2008).

The CREFIAF survey (Dehove 2010) reported that nearly a third of their member bodies followup the extent to which their recommendations have been implemented. This is more common with General State Inspectorates.

The International Budget Partnership (2010) report on Mali noted that:

There is no document that attests to the report of the steps the executive has taken to address audit recommendations of the Accounts Section of the Supreme Court (page 109).

The annual report of the General State Inspectorate in Burkina Faso for 2009 (General State Inspectorate, Burkina Faso 2010) includes a section on following up the recommendations made in the previous annual report. In addition, this General State Inspectorate reviews the extent to which recommendations made by financial and technical inspectorates in each ministry are implemented. The General State Inspectorate received 275 reports from such bodies in 2009 (General State Inspectorate, Burkina Faso 2010).

The annual public report 2008 of the Court of Accounts of Burkina Faso (2009) included a formal follow-up of the recommendations made in its previous four annual reports. This was the first time that such a follow-up had been reported.

In Senegal, the General State Inspectorate is also charged with following-up the recommendations made in all internal audit reports (Keita 2007).

Recommendations made by Courts of Accounts and General State Inspectorates are not usually followed up by these organizations or the National Assembly. However, it is more common for the General State Inspectorates to undertake such a formal follow-up and this may also include recommendations made by other inspectorates or internal auditors. 


\section{Principle 8: Financial and managerial/administrative autonomy and the availability of appropriate human, material, and monetary resources.}

\section{Guidelines}

SAIs should have available necessary and reasonable human, material, and monetary resources - the Executive should not control or direct the access to these resources. SAIs manage their own budget and allocate it as appropriately.

The Legislature or one of its commissions is responsible for ensuring that SAIs have the proper resources to fulfill their mandate.

SAIs have the right of direct appeal to the Legislature if the resources provided are insufficient to allow them to fulfill their mandate.

Few Courts of Audit or General State Inspectorates comply with this principle. None of the 19 member institutions of CREFIAF suggested that they had adequate financial means to fulfil their mandate (Dehove 2010). Only three of these institutions could defend their annual budgets in parliament (two were Court of Accounts and one a General State Inspectorate) (Dehove 2010).

The size of audit institutions in Francophone African countries is far smaller than those in Anglophone African countries. A recent AFROSAI survey found that on average there were 35 auditors for each Francophone member, whilst Anglophone members had an average of nearly 300 auditors each. This disparity in staffing is not explained by differences in the sizes of countries, although the French countries have, on average around half the population of Anglophone countries. But it may be explained, by the existence of more inspectorates or internal audit sections (as they are usually referred to).

In Francophone countries there are a variety of organizations that very broadly undertake similar work to the staff of offices of the Auditors General in Anglophone countries (ex post review/audit of payments). Thus in Burkina Faso, for example there is the Court of Accounts, the General State Inspectorate, the General Financial Inspectorate, the General Budgetary Inspectorate and the General Treasury Inspectorate. In total, these five organizations have approximately 135 professional staff (PEFA, Burkina Faso 2010). In addition, there are also separate inspectorate services for both the customs and the taxation inspectorates. Thus the total professional staffing of all the audit functions in Burkina Faso is comparable to similar sized Anglophone countries, for example, Malawi and Zambia, where the Auditor General has less than 300 professional staff (personal correspondence).

The relatively small size of Supreme Audit Institutions in Francophone countries may also be explained, at least in part, by the level of salaries paid as the French public sector officials generally have higher salaries.

Schiavo-Campo and others (1997) found that:

in franc-zone countries where, by and large, the civil service is much better paid (with wages averaging up to ten times per capita GDP, compared to a continental average of 


\section{5 times per capita GDP) (page 18).}

and

Not coincidentally the size of the civil service in Burkina Faso is relatively modest. (page 20).

The figures for the eight largest Francophone countries suggest that, on average, the Courts of Audit have significantly fewer staff than General State Inspectorates (see table below).

Table 3: Audit Staff of the General State Inspectorate and Court of Accounts

\begin{tabular}{|l|c|c|}
\hline \multicolumn{1}{|c|}{ Country } & General State Inspectorate & Court of Accounts \\
\hline $\begin{array}{l}\text { Democratic Republic of the } \\
\text { Congo }\end{array}$ & 75 (PEFA, 2008) & 65 (AFROSAI) \\
\hline Ivory Coast & 26 (website) & 36 (2008/9 Report) \\
\hline Madagascar & 29 (PEFA 2006) & 56 (personal communication) \\
\hline Cameroon & 124 (AFROSAI) & 22 magistrates \\
\hline Burkina Faso & 22 (personal communication) & 33 (personal communication) \\
\hline Niger & 21 IGEs (2010 decree) & 14 (AFROSAI) \\
\hline Mali & $\begin{array}{c}31 \text { (AFROSAI) } \\
\text { (by law) }\end{array}$ & 15 (Ezeilo 2008) \\
\hline Senegal & 30 General State Inspectors & 42 (AFROSAI) \\
\hline AVERAGE & 45 & 35 \\
\hline
\end{tabular}

In Mali the Auditor General’s Office (Bureau de Vérificateur générale) also had 100 staff including 63 audit staff (ICGFM presentation 2008).

The Courts of Accounts in many Francophone Sub-Saharan African countries are not strong nor well established institutions. In Mali, for example, for many years the Court of Accounts was understaffed, finding it difficult to achieve its objectives and causing a delay in the execution of its tasks. This problem was partly resolved by the increase of the number of magistrates from two in 2000 to nine in 2002 and 15 in 2003. However, the capacity of the Court of Accounts is still largely insufficient. An institutional analysis carried out in 2002, concluded that 60 magistrates would be needed to carry out all the tasks assigned to the accounts court (Ecorys 2006: 83). The Court also suffers from a lack of general personnel (only 40 staff), offices, information, IT and archives (Toure 2004).

The Court of Accounts of the Democratic Republic of the Congo has never been supplied with the resources necessary to implement the law. It was reformed in its current state in 1987. But 
no further recruitment took place for twenty years until 30 auditors were recruited and trained in the second half of 2007 (Cour des Comptes, Democratic Republic of the Congo 2008). On the basis of a meeting with officials of the Court of Accounts in September 2009, the International Budget Partnership questionnaire could report that "None of the national departments are ever audited due to the [Court of Accounts'] insufficient budget” (International Budget Partnership 2010). During a workshop on parliamentary control of public finance in Kinshasa in May 2010, the President of the Court of Accounts, Ernest Izemengia Nsaa-Nsaa, noted that "the Court of Accounts does not have financial autonomy and is dependent on the Ministry of Finance to finance its activities. The Court only receives $10 \%$ of its annual budgetary allocations and this constitutes as serious constraint on the institutions ability to intervene" (ACP 2010). However, things were not better for the General State Inspectorate at least over the period 2003 - 2006, "it could not access its operational budget. It was often manipulated by the ministers in charge to settle their scores with political enemies” (Kodi 2008: page 55).

The annual public report of the Court of Accounts of Madagascar for the financial year 2006 included the following note:

it is important to note the inadequate staffing of the Court of Auditors. The last recruitment of staff was in 1999 and the functions of the Court continue to grow (page $8)^{37}$

In Senegal, the Court of Accounts had 28 magistrates and reporters in 2008 whilst its strategic plan aimed to have 60 magistrates (World Bank 2009). In Senegal the EU paid the salaries for an additional 13 auditors for the Court of Accounts (World Bank 2009). Similarly in Burkina Faso the EU paid for the salaries of 12 assistant auditors (World Bank 2009a).

The budgets of the Courts of Audit are often under the Ministry of Justice (or the Supreme Court in the case of Chambers of Audit) and usually have to be submitted through the Ministry of Finance to the National Assembly. In addition, the Ministry of Finance will usually control the release of budgets to the Court of Accounts (and often the General State Inspectorate).

In Burkina Faso the Court of Accounts and the General State Inspectorate each have their own individual budget lines. But neither institution has sufficient staff. The General State Inspectorate has only 22 professional staff (after recent recruitment) and the Court of Accounts has only 33 magistrates and auditors (12 funded by the EU). One result of this is that in 2008, for example, the Court of Accounts made judgments on only 22 of the approximately 350 local authorities that they should cover.

\section{Independent trade unions}

The independence of Supreme Audit Institutions may also be affected by the right of their staff to join trade unions and to take part in collective action. This right can provide some protection for the staff of these institutions against political interference and the quality of their conditions

\footnotetext{
37 “il importe de noter l'insuffisance des effectifs de la Cour des Comptes dont le dernier recrutement remonte à 1999, alors que ses attributions continuent à croître”
} 
of service. This is recognized in the United Nations' Global Compact (UN, 2000) which is said to have universal consensus and has as the third principle of ten:

"Businesses should uphold the freedom of association and the effective recognition of the right to collective bargaining."

However, this right may be curtailed in a number of Supreme Audit Institutions. In Senegal, for example, the General State Inspectors are prohibited from joining a trade union or a political party and their right to strike is not recognised (Journal Official (Senegal) 2007). Similar restrictions apply for the staff of the General State Inspectorate in Burkina Faso. In contrast, the staff of the Court of Accounts in Burkina Faso and in Madagascar are allowed to join a trade union (personal communication).

In addition, Supreme Audit Institutions may be used as part of a government's campaign against trade unions in general. This was the case in Benin in 2009 after a two-day strike which included demands against corruption and the poor management of public finances (Matinal 2009). As mentioned above, the General State Inspectorate was then used to investigate state funding on the orders of the State President.

Despite such restrictions on the freedom of association of officials of Supreme Audit Institutions, there are several recent examples of such rights being utilized.

The annual report of the Court of Accounts for the Côte d'Ivoire for 2008 - 09 (Court of Accounts, Côte d'Ivoire 2010) indicated that a strike by clerks and administrative staff had disturbed the work of the court throughout the whole of the year.

Members of the Union of the Officers of the Ministry of Control of the State of Gabon started a strike on $1^{\text {st }}$ July 2009 and held a sit-in in the road out-side their offices. They were claiming harmonization of their housing allowance with other ministries and improvements to their conditions of service and said the strike would continue until negotiations were held (Senego 2009).

In Algeria in 2002 the anger of the magistrates of the Court of Accounts surprised public opinion:

The trade union of the magistrates of the Court of Accounts (CoA) mobilized its supporters at the beginning of the year 2002, by publishing a communiqué where it denounced a certain number of ways in which the Court was dysfunctioning and it organzsed a 'sit-in' in front of the headquarters of the institution... (Association Algérienne de Lutte Contre la Corruption quoted in Transparency International 2002: page 234).

The Court of Accounts in Algeria had not had much credibility in the eyes of the public and had not been distinguished by the independence of its action. But the magistrates demanded, "in a spectacular manner”, the establishment of a Council of Magistrates, a reduction in the exorbitant 
powers of the president of the Court of Accounts, against discrimination in promotions and the lack of use made of their official reports (Transparency International 2002).

The presence of women as heads of Supreme Audit Institutions may also suggest progressive and independent organizations. Whilst most of the heads of such organizations in Francophone countries are men, a few are women. For example, a woman has led the Court of Accounts in Tunisia since 1998 and the head of the General State Inspectorate in Senegal since 2005 is a woman.

\section{Conclusions}

In most African countries the external audit functions would benefit from significant strengthening. One recent overview suggested that:

in both Francophone and Anglophone developing countries, the external audit function has not been accorded the priority it deserves. In both regions, external audit offices are often deprived of the necessary financial, human and material resources for carrying out their mandates. Very few developing countries are able to present audited annual accounts to Parliament within 12 months... Finally, when reports become available, they are not acted upon with the seriousness they deserve. This is not so much a problem of the system design, but rather the lack of material and human resources devoted to the external audit function (Ecorys 2006: page 27).

All of the Francophone countries have been challenged to create anew or reform their external audit function in the past decade (Andrews: 40, 2010). The original Code of Transparency (UMEOA 2000) required a Court of Accounts to be established in each member country by December 2002 (rather than there being just a chamber of the supreme court). Despite this not being achieved, the revised 2009 Code just said that the creation of such a court in each member country was obligatory.

Some people claim that General State Inspectorates should not be considered as Supreme Audit Institutions. However, several General State Inspectorates are full and active members of INTOSAI. The General State Inspectorate of Cameroon is currently (2011) hosting the Secretariat of CREFIAF the sub-regional body of Francophone African countries. In 2002 the $8^{\text {th }}$ General Assembly of AFROSAI (the regional body of Supreme Audit Institutions in Africa) was held in Burkina Faso where the General State Inspectorate was the Supreme Audit Institution and it was agreed that they would continue as the Secretary General of AFROSAI for another three years. The General State Inspectorate of Burkina Faso was elected as a member of the Governing Board of INTOSAI for three years from the INCOSAI in 2001 and the General State Inspectorate of Cameroon had been a member until this conference (Kabore 2003).

The independence of the General State Inspectorate is however, demonstrated by the fact that it may lead to the dismissal or even imprisonment of ministers, something that few Auditors General have achieved. The General State Inspectorate (Supreme State Audit Office) in Cameroon led to the dismissal of a former Minister of Health, a Secretary of State for Education and the General Manager of the Fuel Transport Company (personal communication). Similarly, in Senegal a review led by the current General State Inspector resulted in the imprisonment of 
two ministers. This review was undertaken before the General State Inspector was promoted to her current position of Auditor General and head of the General State Inspectorate.

Despite this, the argument against the General State Inspectorate is that they are not independent of the executive and especially the State President, unlike the Court of Accounts. However, the main section of this paper has demonstrated that the two types of institutions have similar levels of independence as summarised in the following table:

Table 4: The independence of the General State Inspectorate and the Court of Accounts compared to the Mexico declaration

\begin{tabular}{|c|c|}
\hline Mexico Declaration principles & Relative level of independence \\
\hline $\begin{array}{l}\text { The existence of an appropriate and effective } \\
\text { constitutional/statutory/legal framework and } \\
\text { of de facto application provisions of this } \\
\text { framework }\end{array}$ & $\begin{array}{l}\text { Court of Accounts marginally better as } \\
\text { usually referred to in the Constitution }\end{array}$ \\
\hline $\begin{array}{l}\text { The independence of SAI heads and } \\
\text { members (of collegial institutions), including } \\
\text { security of tenure and legal immunity in the } \\
\text { normal discharge of their duties }\end{array}$ & Approximately equal \\
\hline $\begin{array}{l}\text { A sufficiently broad mandate and full } \\
\text { discretion, in the discharge of SAI functions }\end{array}$ & $\begin{array}{l}\text { Court of Accounts marginally better as the } \\
\text { General State Inspectorate may more often be } \\
\text { requested to do work by the State President }\end{array}$ \\
\hline Unrestricted access to information & Approximately equal \\
\hline $\begin{array}{l}\text { The right and obligation to report on their } \\
\text { work }\end{array}$ & Approximately equal \\
\hline $\begin{array}{l}\text { The freedom to decide the content and } \\
\text { timing of audit reports and to publish and } \\
\text { disseminate them }\end{array}$ & $\begin{array}{l}\text { Court of Accounts marginally better as annual } \\
\text { reports published in five of the eight biggest } \\
\text { countries, compared to only two countries for } \\
\text { the General State Inspectorate (but this is } \\
\text { increasing) }\end{array}$ \\
\hline $\begin{array}{l}\text { The existence of effective follow-up } \\
\text { mechanisms on SAI recommendations }\end{array}$ & $\begin{array}{l}\text { General State Inspectorate generally better as } \\
\text { more likely to have a formal follow-up } \\
\text { process }\end{array}$ \\
\hline $\begin{array}{l}\text { Financial and managerial/administrative } \\
\text { autonomy and the availability of appropriate } \\
\text { human, material, and monetary resources }\end{array}$ & $\begin{array}{l}\text { General State Inspectorate generally better as } \\
\text { usually have significantly more staff (on } \\
\text { average 45, compared to } 35 \text { for the Courts of } \\
\text { Accounts) }\end{array}$ \\
\hline
\end{tabular}

The above table indicates that for three of the eight Mexico principles the levels of independence of the two types of institution are approximately equal; for three the Courts of Accounts tend to be more independent; and for two the General State Inspectorates are on average more independent. This analysis suggests that both the Courts of Accounts and the General State Inspectorates would both benefit from greater independence rather than one type of entity being significantly more independent than the other. 
This view is confirmed by a senior journalist on one of the major newspapers in Burkina Faso (personal communication):

Neither the Court of Accounts nor the General State Inspectorate is independent of the president nor the executive. The head of each entity is appointed by the State President and so they will only report what they think will be acceptable to the President or the Prime Minister. The General State Inspector sends the annual report to the Prime Minister and it is only published once it has been approved. The First President of the Court of Accounts sends their annual report to the State President and the President of the National Assembly. But they only include information which will be found to be acceptable to the executive.

Both the General State Inspectorates and the Courts of Accounts are experiencing improvements in their independence in a number of countries. Their role is becoming more effective and the resources devoted to these institutions are increasing.

In Francophone African countries the Court of Accounts and the General State Inspectorate can play complementary roles in the audit, review and inspection of the financial management systems of their governments. The original Code of Transparency for the Monetary and Economic Union of West Africa (UMEOA 2000) stated that:

The transparency of the public financial management requires the establishment or the strengthening of the systems of administrative, juridicial and parliamentary control which will ensure the effective and regular audit of public accounts (E2).

The General State Inspectorate is traditionally the supreme administrative control body and the Court of Accounts is responsible for juridical control.

In 2002 Transparency International made the following recommendations for further improvements in the quality of both the Court of Accounts and General State Inspectorate.

\section{Court of Accounts}

- The mission, objectives and the internal regulations should be defined and voted upon by parliament.

- Systems should be developed to protect the autonomy of the magistrates, their nomination and career management.

- The decisions by the Court of Accounts in their evaluation of public accounts should be final and not subject to any further appeal to another body.

- The annual reports of the Court of Accounts should be made public and subject to extensive publicity.

- The Court of Accounts should be provided with the necessary human, financial and material resources to undertake their work. 


\section{General State Inspectorate}

- General State Inspectorates should be able to determine the majority of their annual work programmes

- The annual reports of the General State Inspectorates should be made public and subject to widespread publicity.

- The relevant authorities should take into account the propositions made by the General State Inspectorate, especially when these concern cases of fraud or corruption, and to recommendations to prevent these in future.

- Recruitment to the General State Inspectorate should be by competitive examination to avoid favouritism. Staff should benefit from regulations to protect the security of their positions and their career development.

In some countries co-operation between the Court of Accounts and the General State Inspectorate has improved in recent years. The General State Inspectorate in Burkina Faso is responsible in law for the technical co-ordination of all organs of administrative control. For this reason it organizes an annual meeting for these bodies which the Court of Accounts attends along with the General Inspectorate of Finance, National Co-ordination of the Fight Against Fraud and technical inspection services (General State Inspectorate, Burkina Faso 2010). Similarly in Senegal the General State Inspectorate has the responsibility to encourage and coordinate all the systems of internal control (Keïta 2007).

As with the co-operation between internal audit and the Auditor General in Anglophone African countries, there are a number of ways in which this could be further improved including the following steps (Diamond 2002):

- There should be proper coordination to ensure adequate audit coverage and to minimize duplication of effort.

- There should be access to each other's audit plans and programmes.

- Periodic meetings should be organized to discuss matters of mutual interest.

- There should be an exchange of audit reports.

- Institutional mechanisms should be created to ensure common understanding and sharing of audit techniques and methods.

- Sharing of training and exchange of staff for two to three years in each case.

An effective Supreme Audit function is essential to achieve sound public financial management, but this may be provided by more than one institution. In Francophone African countries, either the Court of Accounts or the General State Inspectorate may be nominated as the Supreme Audit Institution for that particularly country. However, these institutions play complementary roles. Despite significant improvements in recent years, further work is needed to optimize the 
independence, capacity and the resources available to both types of organization and to improve the level of co-operation between them.

\section{References}

African Peer Review Mechanism (2008) Country Review Report of Burkina Faso - Country Review Report $N^{\circ}$ 9, South Africa: African Peer Review Mechanism

ACP (2010) Diagnostic et perspectives de la Cour des comptes en RDC, 50 ans après sa création, Kinshasa: C Retro-Actuel www.scribd.com/doc/48046989/LA-COUR-DESCOMPTES

Adigbli, Koffigan E. (2008) Les inspections d'Etat s'approprient les normes internationales, Dakar : IPS http://ipsinternational.org/fr/_note.asp?idnews=5085

Andrews, Mat (2010) How Far Have Public Financial Management Reforms Come in Africa? Harvard: Kennedy School of Governance web.hks.harvard.edu/publications/getFile.aspx?Id=548

Association des Institutions Supérieures de Contrôle ayant en Commun l’Usage du Français (AISCCUF) website:

http://aisccuf.org/les-institutions-membres/index.html - accessed 11 February 2010

Bizeme, Dr Ezo’o (2010) La Chambre des Comptes de la Cour Supeme - organisation \& mission, Presentation

www.chambredescomptes.net/images/stories/CDCdocs/presentationcdcnew.pdf

Boubacar Issa Abdourhamane and Ivan Crouzel, edited by Marritt Claassens (2004) A Comparison of the Budget Process in France and Francophone African Countries, Cape Town: IDASA

Bouley, D. Fourn el, J and Leruth, L. (2002) How Do Treasury Systems Operate in Sub-Saharan Francophone Africa? (WP/02/58) Washington: IMF. http://www.imf.org/external/pubs/ft/wp/2002/wp0258.pdf

Bouvier, M, Esclassan, M \& Lassale, J (2004) Finances Publiques, Montchrestien: LGDJ (7 edition)

Commission des Finances et du budget (2008) Rapport $n^{\circ}$ 2008-005/an/comfib, Ouagadougou: Assemblee Nationale

Constitution of Burkina Faso (2002)

Constitution of Senegal (2001)

Cours des comptes, Democratic Republic of the Congo (2008) Développement des compétences humaines de la Cour des comptes en République Démocratique du Congo, Presentation at 
AFROSAI meeting

http://courdescomptesci.com/attachments/File/2DRCongo.pdf

Court of Accounts, Burkina Faso, (2009) Cour des comptes, Le Rapport public 2008,

Ouagadougou: Cour des comptes

Court of Accounts, Cameroon (2010)

www.chambredescomptes.net

Court of Accounts, Democratic Republic of the Congo (2009) Audit of Public Expenses for December 2006 to February 2007, Kinshasa: Court of Accounts

Court of Accounts, Ivory Coast (2010) Rapport d'Activites 2008-2009

de la Chambre des Comptes, Abidjan: Court of Accounts

Court of Accounts, Madagascar (2007)

Dehove, Mario (2010) Projet d'Appui au Renforcement Institutionnel des Institutions Superieures de Controle des Finances Publiques de l'Afrique Francophone Sub Saharienne, Yaoundé, Cameroon: Conseil Regional de Formation des Institutions Superieures de Controle des Finances Publiques de l’Afrique Francophone (CREFIAF)

Democratic Republic of the Congo (2006) Constitution de la République démocratique du Congo, Kinshasa:

http://www.ahjucaf.org/spip.php?article764

Diamond, J., (2002) The Role of Internal Audit in Government Financial Management: An International Perspective, Washington: IMF Working Paper 02/94,

ECORYS (2006) External audit - role and quality of the Supreme Audit Institution, Thematic Study 2: Synthesis Report, Rotterdam: ECORYS-NEI and SEOR

Ezeilo, Joy (2008) La Responsabilité Financière dans les finances publiques en Afrique de l'ouest francophone: étude de cas du système de la cour des comptes au Niger et au Mali, Abuja: Centre for Democracy and Development

General State Inspectorate, Burkina Faso (2009) Annual Report for 2008 of the Autorité Supérieure de Contrôle d'Etat, Ouagadougou: ASCE http://www.gouvernement.gov.bf/IMG/pdf_ASCE_Rapport_2008.pdf

General State Inspectorate, Burkina Faso (2010) Annual Report for 2008 of the Autorité Supérieure de Contrôle d'Etat, Ouagadougou: ASCE

General State Inspectorate, Côte d'Ivoire (2010) Website www.cotedivoirepr.ci/index.php?action=show_page\&id_page $=27$ 
General State Inspectorate, Djibouti (2007) Annual Report of the General State Inspectorate, Djibouti

Global Integrity (2006) Global Integrity Report 2006, Washington: Global Integrity http://www.globalintegrity.org/reports/2006/democratic\%20Republic\%20of\%20Congo/scorecar d.cfm?subcategoryID=70\&countryID $=8$

Gueye, Abdou Karim (2008) Inspections générales d'Etat d'Afrique. Réalités, perspectives et enjeux, Djibouti

www.thebookedition.com/inspections-generales-d-etat-d-afrique-Abdou\%20karim\%20Gueye-p2871.html

Institut Montaigne (2005) Un Contrôleur général pour les Finances publiques, Paris: Institut Montaigne

International Budget Partnership (2010) Open Budget Questionnaire Democratic Republic of Congo, Washington, DC: International Budget Partnership www.internationalbudget.org/files/DRC-OBI2010QuestionnaireFinal.pdf

International Budget Partnership (2010) Open Budget Questionnaire Mali, Washington, DC: International Budget Partnership

INTOSAI (2007) Mexico Declaration on SAI Independence, Vienna: INTOSAI

http://www.intosai.org/blueline/upload/issai10mexikodekle.pdf - accessed 11 February 2010

INTOSAI (2007b) INTOSAI Guidelines and Good Practices Related to SAI Independence (ISSAI 11), Vienna: INTOSAI

Journal Official (Senegal) (2007) Loi portant statut des Inspecteurs généraux d’Etat (IGE) Loi nº 2005-23

www.jors.gouv.sn/article.php3?id_article=2643\&var_recherche=inspecteurs+g\%E9n\%E9raux

Kabore, Marie Andree (2003) Audit Profile: The State Audit Office of Burkina Faso, International Journal of Government Auditing, INTOSAI

Keïta, Nafy Ngom (2007) Contrôle et Audit Internes eu Sénégal: état des lieux et perspectives, Marrakech: Vérificateur général du Sénégal

www.aist-tresor.com/Présentation\%20Mme\%20Keita.ppt

Kodi, Muzong (2008) Corruption and Governance in the DRC - during the transition period (2003-2006), Pretoria: Institute for Security Studies

Lienert, I (2003) A Comparison Between Two Public Expenditure Management Systems in Africa, Washington: IMF 
Madagascar (2004) Loi º2004 - 032, Fixant Les Principes Fondamentaux Régissant les Organes Administratifs d'inspection ou de Contrôle, Antananarivo: Presidency

Madagascar (2004) LOI N²004-036 relative à l'organisation, aux attributions, au fonctionnement et à la procédure applicable devant la Cour Suprême et les trois Cours la composant http://aisccuf.org/fileadmin/user_upload/Documents/LOI_N 2004-036_du_28_juillet_2004.rtf

Martin, Gabriel (2010) “Point de presse de l'Inspecteur général d'Etat, M. Gabriel Martin, sur le bilan à mi-parcours des travaux de l'inspection générale d'etat : plus de 64 milliards de FCFA dont 57 de détournement et actes assimilés décelés” 26 December 2010 http://www.tamtaminfo.com/index.php?option=com_content\&view=article\&id=5308:point-depresse-de-linspecteur-general-detat-m-gabriel-martin-sur-le-bilan-a-mi-parcours-des-travaux-delinspection-generale-detat-plus-de-64-milliards-de-fcfa-dont-57-de-detournement-et-actesassimiles-deceles\&catid=44:politique\&Itemid=61

Matinal (17 August 2009) Descente de l'IGE chez les syndicalistes:L'opposition dénonce les intimidations de Yayi Boni

http://www.actubenin.com/?Descente-de-l-Ige-chez-les

Open Budget Initiative (2008) Open Budget Survey 2008, Washington: Open Budget Initiative http://openbudgetindex.org/

PEFA (2010) Mesure de la performance de la gestion des finances publiques au Burkina Faso selon la methodologie, PEFA

PEFA (2008) Mesure de la Performance de la Gestion des Finances Publiques En République Démocratique du Congo http://ec.europa.eu/europeaid/what/economic-support/publicfinance/documents/drc_pefa_report_2008_fr.pdf\#Top

PEFA (2007) Mesure de la performance de la gestion des finances publiques au Burkina Faso selon la methodologie PEFA, LINPICO http://www.finances.gov.bf/SiteFinances/documents/autres/rapport-pefa.pdf - accessed 11 February 2010

PEFA (2006) Mesure de la performance de la gestion des finances publiques au Madagascar selon la methodologie PEFA, Brussels: European Commission http://ec.europa.eu/europeaid/what/economic-support/publicfinance/documents/madagascar_fr.pdf

Presidency of Cameroon website: http://www.prc.cm/index_fr.php?link=2_services_du_controle_superieur_de_l_etat - accessed 11 February 2010 
Prime Minister of Tunisia - website (2010) - Le Contrôle Général des Services Publics (CGSP) http://www.pm.gov.tn/pm/article/article.php?id=12\&lang=fr

Rewmi.com (2007) Nafi NGOM KEITA, chef de l'Inspection générale d'Etat : L'Ige n'est pas un instrument de règlement de comptes politiques, Dakar:

http://www.rewmi.com/Nafi-NGOM-KEITA-chef-de-l-Inspection-generale-d-Etat-L-Ige-n-estpas-un-instrument-de-reglement-de-comptes-politiques_a137.html

SalvatoreSchiavo-Campo, Giulio de Tommaso \& Amitabha Mukherjee (1997) Government Employment and Pay: A Global and Regional Perspective, Washington DC: World Bank http://wwwwds.worldbank.org/servlet/WDSContentServer/WDSP/IB/1997/05/01/000009265_39708181028 36/Rendered/PDF/multi_page.pdf

Senego (2009) Gabon : Le Contrôle d'Etat bascule dans la grève, 2 July http://www.senego.com/gabon/02-07-2009-gabon-le-controle-detat-bascule-dans-lagreve/2009/07/03/343

Sharman, Lord (2001) Holding to Account—the Review of Audit and Accountability for Central Government, London: Stationery Office

Site de L'association des Institutions Supérieures de Contrôle Ayant en Commun L'usage du Français http://aisccuf.org/les-institutions-membres/index.html

Tam, Nguyen Chanh (1990) Finance Publiques Sénégalaise, Paris: L’Harmattan

Tommasi (2010) Gestion des dépenses publiques dans les pays en développement, Paris: Agence Française de Développement http://www.afd.fr/jahia/Jahia/site/afd/lang/fr/pid/75218

Toure, Cheickna (2004) Le Système de Contrôle des Finances Publiques au Mali, Bamako: Université de Bamako http://afrilex.u-bordeaux4.fr/le-systeme-de-controle-des.html

Transparency International (2002) Combattre la Corruption : Enjeux et Perspectives, Berlin : TI

UMEOA April 2010: Directive N01/2009/CM/UEMOA Portant Code de Transparence dans la Gestion des Finances Publiques au Sein de l'UEMOA http://www.uemoa.int/actualite/2009/CM27032009/directive_01_2009_CM_UEMOA.pdf

The Monetary and Economic Union of West Africa (UMEOA) Code of Transparency (2000) United Nations (2000) United Nations Global Compact, New York: UN www.unglobalcompact.org/AboutTheGC/TheTenPrinciples/index.html

Union of Congo (2010) Rattachement de l’Inspection Générale des Finances (IGF) à la présidence de la RD Congo, Paris: Union of Congo 
Wal Fadjri (2009) Nafi Ngom Keita, Chef de mission de vérification de l'IGE sur les chantiers de Thiès: "On a tenté de me corrompre"

http://www.walf.sn/interview/?id_inter=151

World Bank (2009) Training Needs Assessment for the Court of Accounts of Senegal

World Bank (2009a) Training Needs Assessment for the Court of Accounts of Burkina Faso

World Bank (2009b) Training Needs Assessment for the Court of Accounts of Côte d'Ivoire

Wynne, Andy (2010) "Independence of Supreme Audit Institutions in Sub-Saharan Africa”, International Journal of Governmental Financial Management, May -

www.icgfm.org/digest.htm 